\title{
Latinus Scientificus: The History and Culture of Scientific Latin
}

\author{
Barry Wood \\ University of Houston
}

\begin{abstract}
English is the first language of 330 to 360 million people but three times this number speak it as a second language. With an estimated 1.5 billion speakers, it is the most widely spoken language on the planet, though not universal; many regions are bereft of English speakers. A language with few contemporary speakers but widespread use is Latinus Scientificus (Scientific Latin) - a modernized version of the classical Latin of Caesar, Cicero, Horace, Livy, Ovid, and Virgil two thousand years ago. Kept alive by the Roman Church, Latin evolved into the Romance languages (French, Italian, Portuguese, Romanian, and Spanish) and influenced virtually every other European language, including several stages of influence on English. Meanwhile classical Latin continued as the language of learning at the hands of theologians, humanists, and philosophers until the eighteenth century. Then, at the hands of Carl Linnaeus, Latin terminology was systematically developed for botanical description, then adapted for zoology, chemistry, anthropology, and medicine. While spoken and written Latin is now confined to the inner circle of the Roman Church and its official documents, scientific Latin has become the universal language of precise scientific taxonomy and description. The Latinization of personal names and places within scientific Latin reveals it as a still developing language. The influence of Latin as the language of learning and science has led to a more general influence in literature and general culture.
\end{abstract}

Correspondence | Barry Wood, barrywood1940@yahoo.com

Citation | Wood, B. (2019) Latinus Scientificus: The History and Culture of Scientific Latin. Journal of Big History, III(2); pp. $33-46$.

DOI | http://dx.doi.org/10.22339/jbh.v3i2.3230

of the year CE 393, more than eleven centuries
of Olympic Games dating at least to 776 BCE in Greece came to an end. A generation later, in $\mathrm{CE}$ 410, Rome was overrun by the Visigoths. The last Roman emperor, Flavius Romulus Augustus (whose name ironically includes both the legendary founder of Rome and its first and most renowned emperor) was deposed in the year 476 after just ten months, effectively bringing to an end a civilization alleged to have begun more than twelve centuries earlier. Given this apparent end to the Roman Empire, I am somewhat astonished to recall that 1483 years after the fall of Rome, in the year 1959, I graduated from high school with four years of Latin. Our grammar text was Living Latin (1956), a joke among fifteen-year-olds: we routinely referred to our classes in "dead" Latin. My Greek text, White's First Greek Book (1937), escaped such derision.
In those days, the rumor circulated that anyone headed for medical school needed high school Latin because doctors use it to write prescriptions. I wasn't headed for medical school; I ended up in literature and language studies where knowledge of Latin and Greek roots and suffixes has been of continuing use in figuring out the underlying meanings of English words. My University of Toronto bachelor's diploma is printed in Latin; a few years later, my master's and doctoral diplomas were in English-a sign perhaps of the declining status of classical studies. Yet every so often we are reminded that Latin still has currency. In T-Rex and the Crater of Doom (1997), geologist Walter Alvarez titled his second chapter Ex Libro Lapidum Historia Mundi without, we might add, feeling it necessary to provide a translation: Out of Rocks, the History of the World. Later (2015) he used the same Latin as the title of an article with a loose rendering 
in his subtitle, "Reading History Written in Rocks," an aptitude that underlies virtually everything Alvarez has written. For readers unfamiliar with Latin, T-Rex is an abbreviation for Tyrannosaurus rex, The Tyrant King of Lizards, a name that provides an introduction to this paper.

Though the spoken language gradually disappeared, morphing into descendant languages across southern Europe, the Latin language is still with us. Beginning somewhere in the misty history of Rometraditionally founded in the eighth century BCELatin evolved a vocabulary, power, and artistry that resulted in a remarkable historical, philosophical, and literary tradition. It could have died with the Roman Empire but instead it lived on and thrived, adapting to new uses, and was eventually transformed into Latinus Scientificus, Scientific Latin. This paper traces this evolution which is woven through the history of Western civilization, the rise of science, and modern culture. It is an evolution understood in bits and pieces, primarily by linguists, but it has a place in the history of thought, western culture, and big history.

Taxonomic Latin was pioneered and developed by Carl Linnaeus (1707-1778). Today, a modernized and much expanded Latin is now the global language of science-specifically the source of terminology in biology, including both botany and zoology. Using Linnaean binomial nomenclature, 1.2 million terrestrial, ocean plant, and animal species have been named out of an estimated 8.7 million, meaning that an estimated $86 \%$ of species on Earth and $91 \%$ in the ocean have yet to be named (Mora 2011). Approximations of time and cost to complete this work run into hundreds of years and billions of dollars. Collectively, completing this scientific inventory may be the most extensive project in any language, with no end in sight if the aim is to name and classify all living things: the estimate for microbial species ranges from 100 billion to one trillion.

The use of Latin and Greek dominates the formulation of scientific terminology; there really are no other sources for scientific descriptors. But the creation of scientific words is not simply a matter of random borrowing; it has developed into a systematic linguistic process.

Illustration 1. Roland Wilbur Brown's book, Composition of Scientific Words, at 882 pages, provides some indication of the process of science word creation and the extent of scientific terminology developed from Latin and Greek.

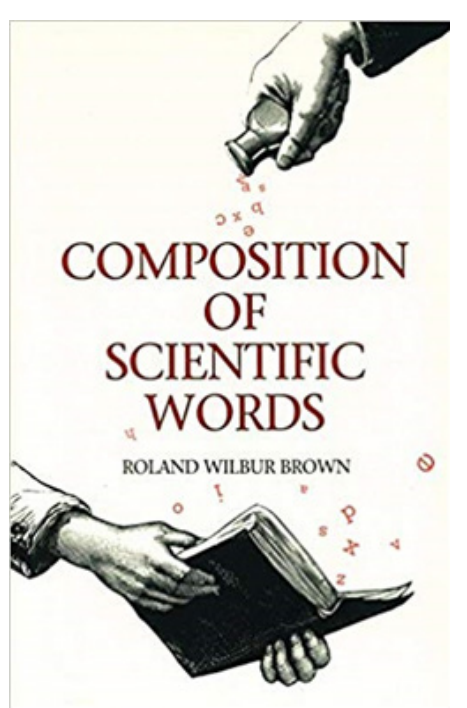

The story of how Latin survived the demise of the Roman Empire to become the medium for this vast enterprise constitutes a cultural history of great interest that includes its extension into other sciences: anthropology, chemistry, geology, and medicine. Latin, along with an infusion of borrowed Greek, was an evolving language throughout the Roman era (753 BCE-CE 476), but the classical Latin that later scholars admired and emulated dates from its central period, 100 BCE to CE 50. During the European Renaissance, scholars idealized classical Latin and writings of this era. Julius Caesar's De Bello Gallicus (On the War in Gaul) is simple and strikingly clear; one thinks of Hemingway in English. Cicero's De Natura Deorum (On the Nature of the Gods) and Livy's multi-volume History of Rome provide the benchmarks for classical prose. In poetry, Horace's Odes, Virgil's Aeneid, Ovid's Metamorphoses, and Lucretius' On the Nature of Things define the artistic power of the Roman language. During the later imperial era, Latin declined somewhat in expression and power, and is known as Latinus vulgare (Common Latin). It is best understood as the spoken language of Roman soldiers, settlers, and conquered 
people, particularly in Southern and Western Europe. Isolated from stabilizing written forms and influenced by earlier indigenous tongues, Common Latin quickly developed into separate languages known today as the Romance languages: French, Italian, Portuguese, Romanian, and Spanish-this last having the second largest number of speakers in the world today after English. Characteristics unique to Classical Latinnoun declensions, verb conjugations, verbs at the end of sentences with inflection the key to meaning-have largely disappeared in these descendants. Word order of noun-verb-object with extended use of prepositions has become a major key to meaning.

Apart from these descendants, the influence of Latinus vulgare is evident in loanwords in almost every other European language: Albanian, Czech, Danish, Norwegian, Polish, Russian, Slovakian, Swedish, and Ukranian. This influence of common Latin vocabulary, if not its artistry, traces to its adoption as the sacred language by the Roman Church. The conversion of the Emperor Constantine in CE 312 effectively defined Christianity as the official religion of the Roman Empire a century and a half before its fall, adding authority to all Christian writings across Europe. The earliest New Testament gospels were composed in Vetis Latina (Old Latin), but in 382 Pope Damasus commissioned Jerome to do a complete translation into Latin which is now known as the Versio Vulgata, the "version commonly used," abbreviated to The Vulgate, which was so widely recognized that it was eventually confirmed as the official Bible of the Roman Church at the Council of Trent (CE 1545-1563). Through the first fifteen centuries of the Common Era, continuation of Latin in the Romance languages and its use by the Church made Latin the most influential language in Europe.

Latin itself is a descendant of earlier tongues broadly grouped as "Italic," most of which, like Etruscan, are long extinct. Tracing language to ultimate origins may be impossible because spoken words are ephemeral: they disappear into thin air, and written language extends no more than 5000 years into the past. It has been a feat of ingenuity that we have reconstructed the parent of the Italic languages, and indeed of a dozen other branches, to a hypothetical Indo-European (IO) parent estimated to have been spoken between 6000 and 8000 years ago somewhere in the region of the Black Sea.

Original Indo-European roots can be reconstructed from the vocabularies of living Indo-European languages and known sound changes to produce a tentative Indo-European vocabulary.

This does not mean that we instantly recognize every descendant of Indo-European; a first glance at the Germanic tongues does not suggest an affinity with Latin. With several millennia of isolated evolution, the Germanic and Italic branches had become mutually unintelligible by the early cenrturies of the Common Era, at which point we can identify a Latin word that has crept into German as a foreign presence. This is where Latin first begins its influence on English.

It began during the Imperial Era following the deification of Augustus (27 BCE) with Latin vocabulary seeping into West Germanic on the Continent, then carried into Britain by the Angles, Saxons, and Jutes. Approximately 175 Latin words borrowed from Latin into West Germanic survived loss on the Continent and obsolescence or extinction in England to become embedded in Old English (Serjeantson, 1935, 271277). A second influence occurred following the recall of the Roman military from England (CE 410). Between then and the Norman Conquest (CE 1066): another 500 Latin loanwords recognizable today found their way into Old English (Serjeantson, 277-288). A substantial cluster of religious words in English originated with the transfer of Christianity directly to Britain: Latin apostolus, credo, crucem, discipulus, and martyr survive as apostle, creed, crucifix, disciple, and martyr.

Following what purist linguists Thomas Algeo and John Pyles $(2005,124)$ called "the great catastrophe of the Norman Conquest," a third wave of Latin influence occurred through Norman French, the language of a newly installed monarchy and aristocracy imposed 
on the laboring classes of Feudal Britain. From the $11^{\text {th }}$ to $14^{\text {th }}$ centuries, thousands of Latin-throughNorman French words were added to English, notably in subjects like religion, law, and privileged living. Science was virtually undeveloped during the Middle Ages; thus scientific words from Latin (sometimes with earlier origins in Greek) in English were confined to simple astronomical and geographical terms (comet, equator, circumference), names of plants (asparagus, delphiniums, juniper, lilies, roses, violets), animals (asp, locust), and minerals (copper, onyx). A fourth influence occurred during the $15^{\text {th }}$ and $16^{\text {th }}$ century when a revived interest in classical culture and learning led to numerous additions of words formed from Latin roots. Typically these additions were of a general nature: area, innuendo, census, curriculum, impetus, radius (Serjeantson, 264-265).

Sometime during the late Old English period, vowel sounds began to soften, hastened later by the influence of Norman French. The velar stop inherited from the Germanic parent language abated, softening the pronunciation of many consonants. These changes, along with the infusion of Latin vocabulary, moved English from a Germanic tongue to a midposition between the Germanic and Italic branches of the original Indo-European parent language. James Lovelock $(1988,17)$ has remarked that "the tribal war between the Normans and the Saxons was long enduring: the medieval schoolman, knowing where power and preference lay, chose to support the Victorious Norman establishment and to keep Latin as their language." Latin for the schoolmen, the Norman descendant of Latin for the people: this made English even more open than most other European languages to Latin influences with massive additions of Latinorigin roots through the era of Renaissance humanism and the rise of science. Melvyn Bragg (2003, 109-120) characterized this period as "a Renaissance of words." Many Latin additions to English were unchanged in spelling; the fact that many of these (bacteria, corona, fungus, opus, strata, and virus) are now regarded as our own reveals how compatible English had become for Latin additions.

The influence of Latin on other European languages is evident though not so pervasive. As noted, its medium was primarily religious works. Throughout the period of Roman Church dominance, Latin was the language of creeds, theology, and such landmark religious works as Augustine's Civitas Dei (City of God), Boethius' Consolatio Philosophia (Consolation of Philosophy), and Thomas Aquinas' Summa Theologica (Complete Theology), and it continued beyond the fold of the Roman Church in John Calvin's Institutio Christianae Religionis (Institutes of Christian Religion) as the Protestant Reformation redefined the foundations of Christian authority.

Illustration 2 . John Calvin's Christianae Religionis Institutio (1536), translated into English as Institutes of the Christian Religion (1559), became the defining source of Protestant religion, including the Puritan migrants to the American colonies. The dividing of title words, Christia/ nae and Insti/tutio may indicate limitations in available typeface sizes.

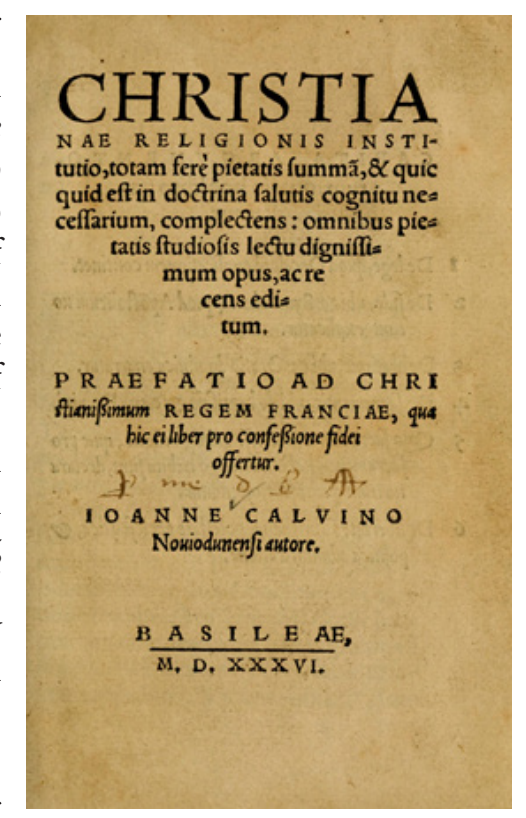

The influence of Latin during the Medieval period can hardly be overstated, as massive documentation in Ernst Robert Curtius' European Literature and the Latin Middle Ages (1948) makes clear.

During the Renaissance, Latin influence grew to become the medium for a variety of secular works. In 1509, Disiderius Erasmus (1466-1536) published his satirical Stultitiae Laus or Moriae Encomium (In Praise of Folly). In 1516, Thomas More published his political satire, Utopia (No place); though his title is drawn 
from Greek, the work was written in Latin. One of the earliest novels written in Latin, Johannes Kepler's 1608 Somnium (The Dream), has been recognized as early science fiction. In the $16^{\text {th }}$ and $17^{\text {th }}$ centuries, the earliest works in science were published in Latin. On his deathbed in 1543, the Polish Copernicus released his De Revolutionibus Orbium Coelestium (On the Revolution of Heavenly Orbs) which set forth his heliocentric theory of the solar system. In 1610, The Italian Galileo reintroduced the theory in Siderius Nuncius (The Sidereal Messenger). In 1620 the British essayist and philosopher Francis Bacon set out the principles of observation and deduction in Novum Organum Scientiarum (New Instrument of Science). The Danish physician Nicholas Steno, who relocated in Italy, confronted the mystery of animal fossils enclosed in rock in De Solido intra Solidum (On a Solid inside a Solid ); in 1641 the philosopher Descartes completed Meditationes de Prima Philosophia (Meditations on First Philosophy), setting out a new approach to philosophical certainty; the Portuguese born philosopher Baruch Spinoza's magnum opus, Ethica appeared in 1677; and the British mathematician Isaac Newton laid out the principles of calculus in Principia Mathematica (1687).

The most dramatic influence of Latin in the sciences was in biological description. Detailed descriptions of plants originated millennia earlier with a disciple of Aristotle, Theophrastus of Eresos (370-c. 285 BCE), whose De Causis Plantarum (On the Origin of Plants) and De Historia Plantarum (On the History of Plants) have survived. His insights, along with those of numerous other Greek and Roman writers, were consulted by Pliny the Elder (CE 23-79). In the development of Latin as a descriptive language for botany, one can hardly overestimate the influence of Pliny's Historia Naturalis (Natural History) which went through 190 Latin editions between 1469 and 1799. Pliny adopted Latin words metaphorically and thus supplied a few familiar botanical termscorona, pistillum, and pollen-and numerous others
Illustration

Galileo's

Siderius

Nuncius (1608),

translated as The Starry Messenger (1610), presented the heliocentric theory of the Universe which led to his inquisition in Rome, forced renunciation of his theory, and house arrest for the last eight years of his life.

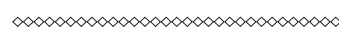

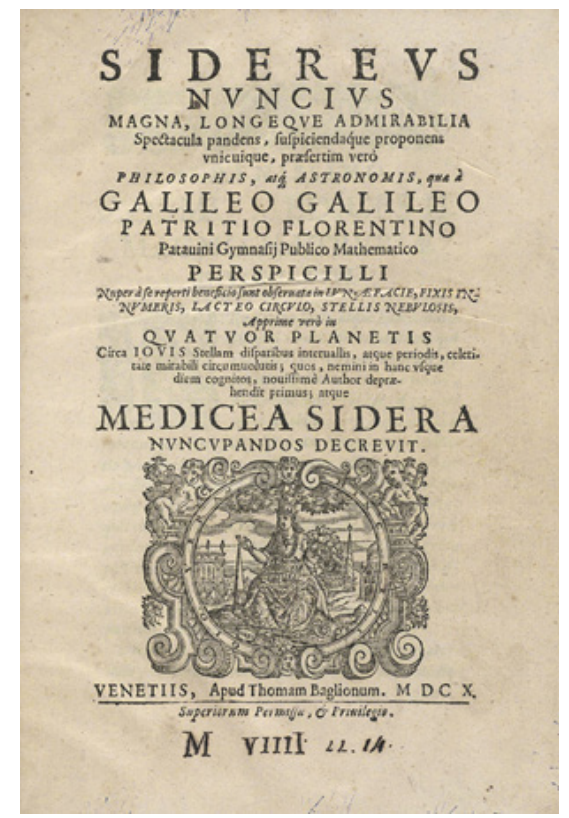

recognizable only by professional botanists. Pliny's influence is seen in the 1601 Rariorum Plantarum Historia (History of Rare Plants) by Cariolus Clusius (1526-1609).

The most extensive pre-Enlightenment use of Latin for botanical description came from the English botanist John Ray (1627-1705) whose 3,000-page Historia Plantarum, divided into three massive folios (1686-1704), described an astonishing 18,000 species. Ambitious it was, but his planned illustrations were never included for lack of funding. Moreover, Ray's encyclopedic inventory of plants was not informed by an overriding classification system; in fact, as Paoli Rossi $(2000,179)$ notes, "Ray did not believe . . that nature could be geometrically and symmetrically arranged." Though vast, his was the last inventory of plants uninformed by some sort of orderly system. Meanwhile Joseph Pitton de Tournefort (16561708), a French botanist at the Jardin des Plantes in Paris, published Elements de Botanique (1696), then republished it in Latin as Institutiones Rei Herbariae (1700) where, in the introduction, he explained his classification system based entirely on genus with distinctions drawn from morphological differences in the corolla, the reproductive parts of flowers. Using this constricted methodology, Tournefort described 
more than 10,000 species classified into nearly 700 types. While not as comprehensive as Ray's History of Plants, as Julius von Sachs $(1890,78)$ pointed out, Tournefort's striking illustrations made from copperplate engravings along with felicity of description made his works popular and influential in the eighteenth century until displaced by the mid-century work of Carl Linnaeus.

The development that took botanical description beyond mere inventory occurred with Linnaeus' linguistic revolution which laid out the parameters for scientific description and notation that established Latin as the universal language of science. He could have chosen to write in Swedish, but this might well have reinforced a trend toward separate vocabularies for science in the numerous vernacular languages of Europe and elsewhere. His influence lay first in a variety of Latin treatises produced between 1736 and 1753: Fundameta Botanica (Botanical fundamentals), Genera Plantarum (Origin of Plants), Philosophia Botanica (The Science of Botany), and Species Plantarum (Plant Species). His encyclopedic coverage in Latin established these as standard works that scientists all over Europe could and did consult. Second, Linnaeus utilized available terms as they had been used in previous works ever since Theophrastus and Pliny while remaining true to established lexical definitions. As William T. Stearns (1992, 34-35) put it, "he selected from the classical words converted into technical terms by his predecessors those which seemed apt, pleasing, and unambiguous." His third contribution was the adoption of Latin words for botanical use with no regard for their original classical meanings. An instructive example from his 1736 publication, Fundamenta Botanica (Fundamentals of Botany) is corolla- "a little crown or garland" in classical usage-which he adopted specifically for the prominent attractive surround of a flower's sexual parts. Richard Robinson (1950) has distinguished this usage from lexical definition by what he calls "stipulative definition," an arbitrary but creative distillation of new meanings for classical vocabulary.
Such terminology carries the flavor of classical Latin put to new uses, though such stipulative definition has recurred in numerous fields and could hardly be avoided throughout the history of science.

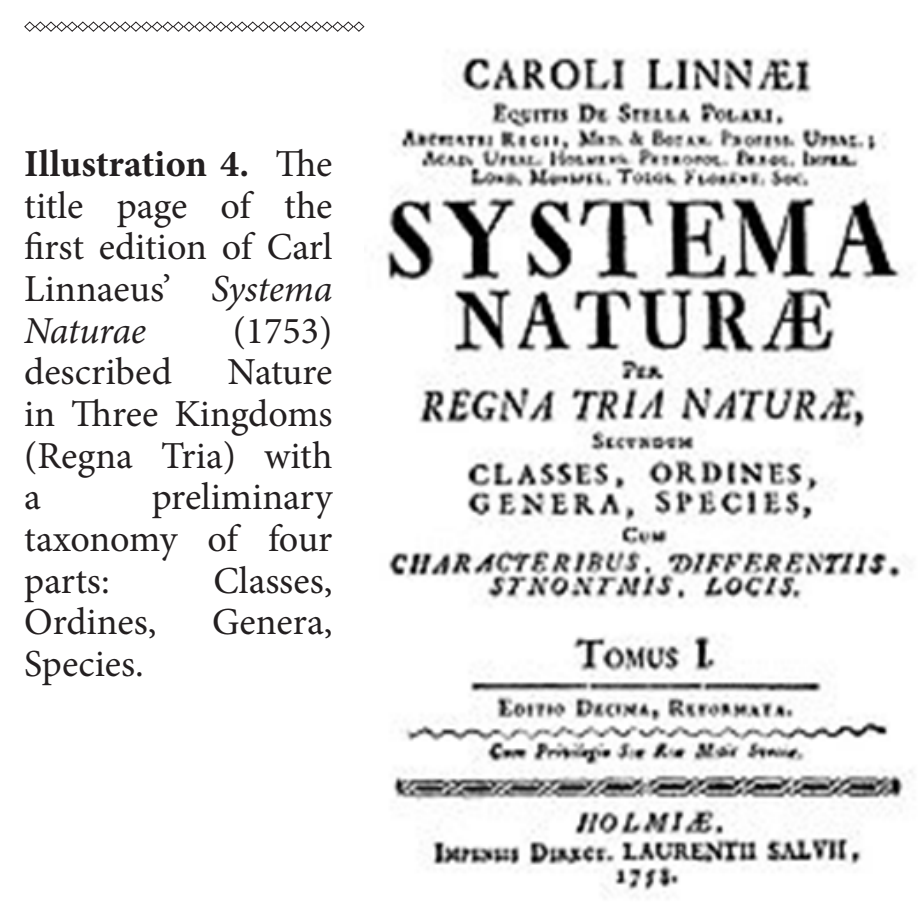

Linnaeus' most significant innovation was a full-fledged development of botanical description commenced in Systema Naturae (1735) with his most comprehensive treatment occurring in the tenth edition (1758) and considerably enhanced in the twelfth edition (1766-1768). In the expansive style of early books, Linnaeus' title page of the early edition already displays his four-part organization-Classes, Ordines, Genera, and Specie-the foundation of a classification system, or taxonomy, now universally adopted. In practice, Linnaeus adopted a twopart identification system now known as binomial nomenclature. As Paoli Rossi $(2000,175)$ remarks, in Linnaeus' settled binomial nomenclature, two terms contain "an astounding wealth of information. . . . the first defines its genus and the second its species, distinguishing it from all others of the same genus. 
... The identification of a species is not simply the identification of differences but also the recognition of similarities to others of the same genus."

In the fully developed system, the sequence proceeding from the specific (aptly named "species") to the general expands Linnaeus' four levels to seven: Species, Genus, Family, Order, Class, Phylum, and Kingdom. Thus in identifying an oak treelet's say Quercus alba, white oak of Eastern North America-alba (white) signifies one of 600 species belonging to the genus Quercus (oak) which is part of the family Fagaceae of the order Fagales, one class of Magnoliopsida, of the phylum Anthophyta of the kingdom Plantae. While most of the intermediate terms are unfamiliar, the final term identifies an oak tree as part of a broad category of Plants. In similar fashion, in the familiar designation of modern humans, Homo sapiens, our species sapiens is one of several extinct species (erectus, habilis, neanderthalis) in the genus Homo, which is part of the family Hominidae within the order Primates, part of the class Mammalia which belongs to the phylum Coradata within the kingdom Animalia-once again a recognizable category. In Linnaeus' nomenclature, these two kingdoms, Plantae and Animalia, marked the limit of classification in the eighteenth century. Lynn Margulis' Five Kingdoms (1982) has added three more: Monera, Protoctista, and Fungi.

In 1750 , fourteen years after the publication of his Fundamenta Botanica (1736), Linnaeus expanded its thirty-six pages to a 364-page book he called Philosophia Botanica, with eleven illustration plates. Stearn $(1992,35)$ defines it as "the first textbook of descriptive systematic botany and botanical Latin." Its influence is evident in translations and expanded illustrated versions that soon appeared in England, France, and Germany. Meanwhile, with the generation of new knowledge, new vocabulary was needed, and Latin became the source. But classical Latin, despite its extensive linguistic richness, could not support the linguistic needs of new learning. It was here that a new kind of Latin was developed: vocabulary conforming to the structure of Latin linguistic prefixes, suffixes, and roots was created.

By the nineteenth century, binomial nomenclature and a supporting Latin vocabulary of plant stems, leaves, blossoms, and colors was developed enough that plants could be observed and identified without supporting illustrations. This is hard for us to imagine today because we rely on the extensively illustrated Peterson or Smithsonian field guides. Early plant observers were evidently refined observers. Jacob Bigelow's 1814 Florula Bostoniensis (Flowers of Boston) became the working handbook for Henry David Thoreau (1817-1862), who studied plants, flowers, and trees throughout his and his brother's excursion narrated in A Week on the Concord and Merrimack Rivers (1849), his two-year life in the woods recorded in Walden (1854), and three expeditions combined in Cape Cod (1865) His botanical knowledge is evident in posthumous works where we find comprehensive lists in Linnaeus' binomial form as appendixes to The Maine Woods (1864) and his much delayed "lost manuscript" recovered and published as Wild Fruits (2000). After twelve years of work, the painter John James Audubon published his life's work, 435 paintings titled The Birds of America (1839). Every illustration carries both the common name and the Linnaean scientific name.

In a context far removed from Linnaeus' Sweden, Thoreau's New England, or the broader canvas of Audubon's America, the Greens Bayou Wetlands Mitigation Bank (2006) provides an inventory of species on 1,450 acres of wildland preserve in Houston, Texas. Here we find Hyla cinerea (green tree frog) among 14 amphibians; Procyon lotar (raccoon) among 15 mammals; Micropterus salmoides (largemouth bass) among 22 fish species; 15 reptiles, including the American alligator, copperhead snake, and Texas coral snake; 70 invertebrates such as bees, beetles, ants, and butterfly species; and over 450 species of vegetation-a total of 550 species of flora and fauna identified by both Linnaean binomial nomenclature and common English names. Such exhaustive inventories are most 


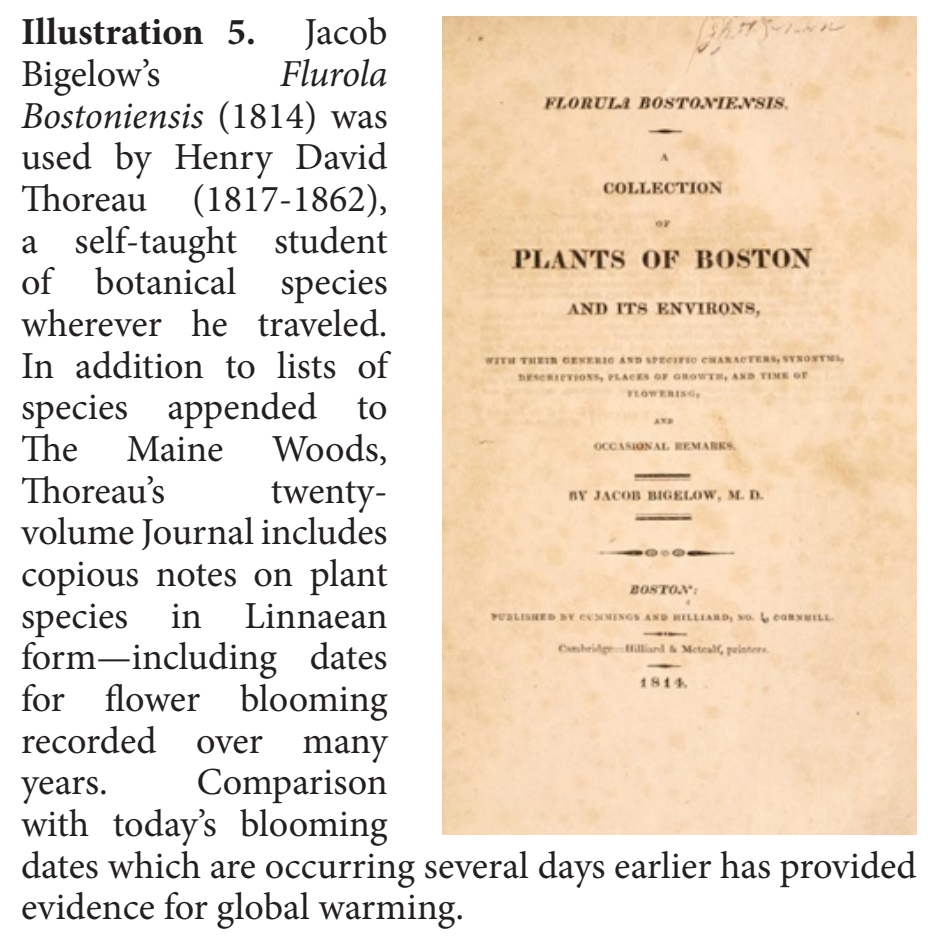

often found on limited tracts set aside for study as well as preservation. Selective inventories have been compiled for the carefully gathered trees and plans of The Royal Botanic Gardens, Kew, in London (Utteridge and Bramley 2016) and the Singapore Botanic Gardens (Sim 2017)-preserved species dating to the days of the British Empire. Wildflowers attract our attention more than purely green plants. Consequently, a wildflower emphasis is found in plant inventories of extensive wildland regions in the United States: the Florida Everglades (Hammer 2015), the Sierra Nevada Mountains explored by John Muir (Wiess 2013, Wenk 2015), the Great Smoky Mountains National Park (Stupka 1964), and most other national and state parks. Oceanographic inventories of coral and sea creatures lie behind the creation of undersea preserves such as the northwest Hawaiian seamount chain (Fenner 2005, Hoover, 2010). Such Linnaean inventories turn up from distant regions of diverse linguistic backgrounds, Southeast Asia, for instance: Mangrove Forests of the Malay Peninsula (Watson 1928); Fruits of Bali (Eiseman 1988); Birds of the
Philippines (Kennedy 2000); and Field Guide to the Reptiles of Thailand (Chan-ard 2015).

An innovative modification of Latin is evident in Linnaeus' 1737 Flora Lapponica (Flowers of Lapland), the result of five months of travel in Lapland. The title provides a Latinized name for Lapland and stands as an early regional field guide to flowers. His 1744 Flora Svecica (Flora of Sweden) provided the same for Sweden. Latinized geographical names continue to appear in the species position in Fulica americana (American Coot), Quiscalus mexicanus (Great-tailed Grackle), Melospiza georgiana (Swamp Sparrow), and Sylviagus floridanus (Eastern Cottontail)generally indicating where a specific species was first identified. Peking Man, found near the capital of China in the 1920s, was originally called Sinanthropus pekinensis which incorporates Latinized versions of "China" (Sina) and the anglicized "Peking" (Beijing). This hasty designation has become entangled with the Multiregional Evolution Hypothesis (MEH) in opposition to the Recent Out of Africa Hypothesis (ROAH) for modern humans, with continuing Chinese reticence and criticism of the ROAH ( Wu 2004) and belief in an Asian origin and Chinese evolution from Sinathropus pekinensis rather than an africanus ancestry. However, recognition of Peking Man as a descendant of the African Homo erectus species has superseded the MEH.

Another revealing innovation is found in Linnaeus' 1738 Hortus Clifforianus (Clifford's Garden), written in Holland while Linnaeus was a guest of the wealthy banker, George Clifford, governor of the East India Company, was an enthusiastic botanist who had developed a large herbarium. The naming of species for discoverers is another innovation of botanical Latin. During the British stewardship of Indonesia, Sir Stamford Raffles (1781-1826) served as Lieutenant Governor of Java (1811-1815), later Bencoolen in Sumatra (1817-1822). Famous for founding Singapore, he is also the famous for a drink, the Singapore Sling (a gin-based cocktail), invented in the Raffles Hotel. During an expedition in Sumatra, he and Joseph 
Arnold discovered a giant parasitic plant whose name now celebrates both discoverers: Rafflesia arnoldii. The renowned and widely published entomologist, Edward O. Wilson, noted for his study of ants is honored in several ant species: Wilsonia megagastrosa, Wilsonia lianoingensis, and others.

Latin in the service of botany has been the most fully articulated, thanks to the exhaustive work of William T. Stearn (1911-2001), known for scores of publications, including Dictionary of Plant Names (1972) and Flower Artists of Kew (1990). His magnum opus, Botanical Latin, subtitled History, Grammar, Syntax, Terminology and Vocabulary, has gone through four editions (1966, 1973, 1982, 1992), multiple reprintings, and translation; it is renowned among botanists worldwide.

Illustration 6. William T. Stearn's Botanical Latin includes the basics of Latin conjugation, declension, grammar, terminology, and binomial nomenclature.

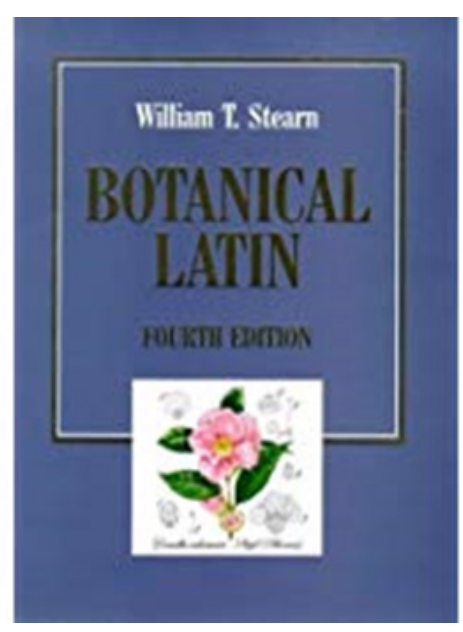

Interestingly, once botanical Latin was securely established in the eighteenth century, it subsequently spread well beyond biology. Chemical elements, most of which were isolated later, thus have classical etymologies indicating roughly equal origins from Greek and Latin. Element names from the Greek often derive from Greek deities or mythological figuresHelium (Helios), Iridium (Iris), Niobium (Niobe), Plutonium (Pluto), Promethium (Prometheus), Selenium (Selene), Tantalum (Tantolos)-with their endings routinely Latinized. Elements from Latin sometimes honor deities-Mercury (Mercurius),
Cerium (Ceres), Neptunium (Neptune); more often they preserve Latin names for substances or qualitiesCalcium (calx), Carbon (carbo), Copper (cyprum), Tellurium (tellus), Silicon (silicis). When new chemical elements are named to honor eminent historical figures, they are regularly provided with Latin endings: Copernicium (Copernicus), Curium (Marie Curie), Mendelevium (Dmitri Mendeleyev), Fermium (Enrico Fermi), Rutherfordium (Ernest Rutherford), Einsteinium (Albert Einstein), and Nobelium (Alfred Nobel).

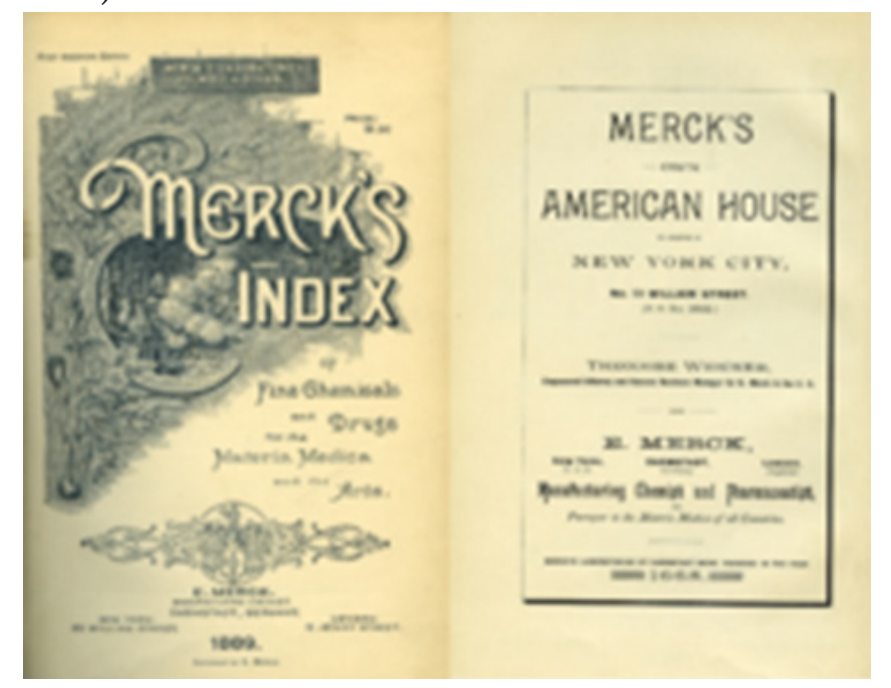

Illustration 7. The first edition of Merck's Index, published in 1889. This encyclopedic tome is now in its $15^{\text {th }}$ edition.

Elements in their raw form, particularly metallic elements, are of value for human use in many ways, well illustrated by Aluminum, Iron, Copper, Gold, Silver, and Tin. In combination, they have numerous industrial and technological applications. However, The Merck Index, first published 129 years ago, now in its $15^{\text {th }}$ edition, extends chemistry into medicine and pharmaceuticals. Recent editions which are subtitled An Encyclopedia of Chemicals, Drugs, and Biologicals, include more than 10,000 entries. Many of them are simple compounds, some are organic extracts. Listings, even if they contain three or more elements, typically imitate the binomial nominclature of Linnaean botanical taxonomy. Manganese Chloride has two 
components $\left(\mathrm{Cl}_{2} \mathrm{Mn}\right)$; Sucrose Octaacetate contains three $\left(\mathrm{C}_{28} \mathrm{H}_{38} \mathrm{O}_{19}\right)$, Aluminum Ethoxide contains four $\left(\mathrm{C}_{6} \mathrm{H}_{15} \mathrm{AlO}_{3}\right)$, Mecysteine Hydrochloride contains five $\left(\mathrm{C}_{4} \mathrm{H}_{10} \mathrm{ClNO}_{2} \mathrm{~S}\right)$, Pyridinium Chlorochromate contains six $\left(\mathrm{C}_{5} \mathrm{H}_{5} \mathrm{ClCrNO}_{3}\right)$. These and most other chemicals are most often referred to by their English names; for instance, iron sulphate and potassium nitrate; but when these are incorporated into chemical descriptions, they are Latinized-ferri sulphas, kalii nitras. There is, indeed, much to learn if one is to navigate this vast Latinized landscape. The rumor of my high school years that students heading for medical studies should take Latin is no longer supported by high school curricula; medical students now typically enroll in quick-take courses in "medical Latin."

English as the most widely spoken language in the world has been exceptionally receptive to scientific Latin. To a large extent this is the result of the many more general Latin words that have been preserved in English so easily that an educated reader hardly distinguishes them as foreign. Thus, we run across familiar Latin terms in a variety of general contexts: $a d$ hoc, a priori, argumentum ad hominin, de facto, deus ex machina, ipso facto, magnum opus, modus operandi, non sequitur, per se, quid pro quo, reducto ad absurdum, and terra firma. Philosophers are known by a Latin phrase-Descartes by cogito ergo sum, Locke by tabula rasa, Freud by ego and $i d$. Academics still title a list of their credentials as curriculum vitae. John Dryden published a poem called Annus Mirabilis to celebrate the survival of London in 1666 following the Great London Fire. The term has been applied to 1543, the year Copernicus released his heliocentric theory; 1776, the year of American Independence; 1905, the year Einstein published his General theory of Relativity; and dozens of other years of significance in the lives of the famous. When Queen Elizabeth II spoke at the end of 1992, a year of royal family scandals, divorces, and the devastating fire at Windsor Castle, she evoked a Latin term, Annus horribilis.

Undoubtedly, Cicero, Virgil, and Lucretius would be astonished to discover that their language has survived and expanded over two millennia and is now the only truly universal language. In its penetration into the scientific community, it surpasses even English. Unaware of the stature of their language in later cultures, Roman writers would be puzzled by books with Latin titles written in an unrecognizable language: the three-volume tome by Alfred North Whitehead and Bertrand Russell, Principa Mathematica (1910), and Ludwig Wittgenstein's translated Tractatus Logico-Philosophicus (1921), both written in English. From another perspective, today's college students documenting their essays are equally puzzled by the purpose of Latin fossils like et al, loc cit, and op cit.

The history of Latin in science, literature, and general culture reveals a penetration of this ancient language far more extensive than we usually recognized. A comprehensive exploration and inventory of its extensive applications, as Stearn's 546-page Botanical Latin or the 1818-page Merck Index well illustrate, might require as many volumes as an encyclopedia. In this connection, we are reminded of one of the most influential works of many volumes, published between 1768-1771 during Linnaeus' lifetime-the most important work of general knowledge in English; interestingly, its title preserves the Linnaean genusspecies structure of botanical Latin: Encyclopedia Britannica.

Latin is useful as a scientific and technical language because it is a written rather than spoken language and is therefore immune to vocal anomalies, vowel changes, consonant variations, and colloquial modification. Vocabulary additions and inventions occur, but the roots and elements utilized in the addition of new terms are fixed. No one speaks Latinus Scientificus, but scientists in every corner of the world find permanent coordinates of meaning in a structure formalized more than two centuries ago. It is pervasive, so much so that it has an influence well beyond what may have been intended. Various European literary works have been translated into Latin: the Italian Divina Comoedia (Divine Comedy), Spanish Dominus Quixotus a Manica (Don Quixote), Portuguese Lusiadae (Lusiads), 
German Werther Iuvenis Quae Passis Sit (Sorrows of Young Werther), and the English novels Rebilius Cruso (Robinson Crusoe), and Superbia et Odium (Pride and Prejudice). Translation of novels into Latin in the twentieth century has virtually disappeared; a notable exception is the Latin translation of George Orwell's 1944 novel, Fundus Animalium (Animal Farm), an anachronistic oddity.

Yet the vitality of Latin lives on, even while it has almost disappeared from high school and college curricula. The translation of fairy tales and children's books provides an entertaining and humorous indicator of Latin's prestige and vitality.

\section{Illustration 8 . \\ Clive Harcourt Carruthers' Latin "reddidit" ( $t$ ranslation) of Alice in Wonderland includes a Latin rendition of the original author's p s e u d o n y m, Lewis Carrol. Etymologically, Ludovicus is a Latinized version of the German name Hluwig, which renders into English as Louis or} Lewis. Carrol's real name was

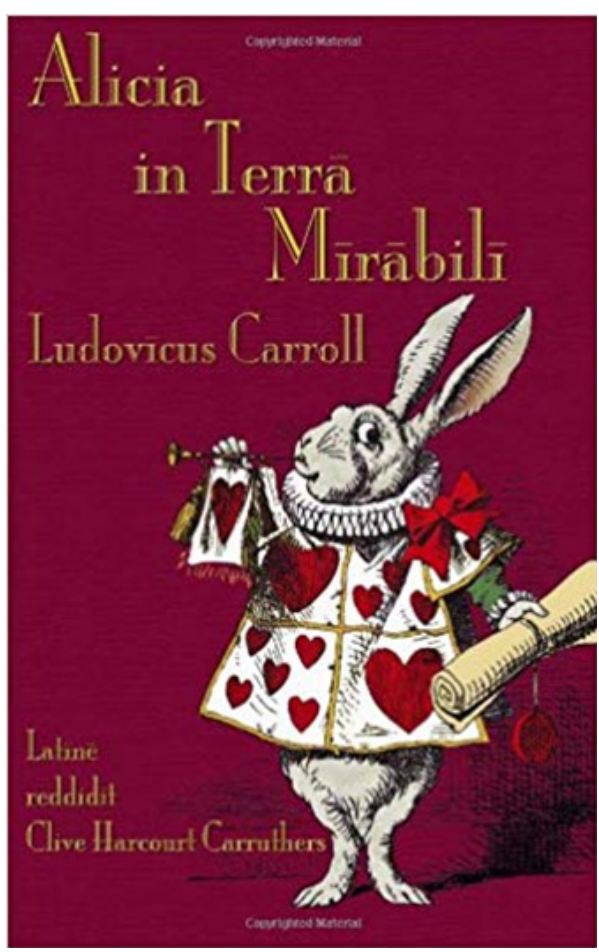

Charles Lutwidge Dodgson, his middle name being the original of Ludovicus - a convenient illustration of the tangles of vocaculary transfer.

This includes such classics as Alicia in Terra Mirabili (Alice in Wonderland), Insula Thesauraria (Treasure Island), Pericia Thomae Sawyer (Adventures of Tom Sawyer), Beata Illa Nox (The Night Before Christmas),
Fabula De Petro Cuniculo (The Tale of Peter Rabbit), Winnie Ille Pu (Winnie the Pooh), Hobbitus Ille (The Hobbit), Tela Charlottae (Charlotte's Web), Cattus Petasatus (The Cat in the Hat), Virent Ova! Virent Perna! (Green Eggs and Ham), Arbor Alma (The Giving Tree), Ubi Fera Sunt (Where the Wild Things Are), and Quomodo Invidiosulus Nomine Grinchus Christi Natalem Abrogaverit (How the Grinch Stole Christmas).

The effect is an entertaining placement of children's books alongside the greatest scholarly works of the Western world by Galileo, Newton, and Wittgenstein. But there seems to be a serious side to this anachronism. Getting children started in Latin aligns rather well with the current American Association for the Advancement of Science (AAAS) efforts through Next Generation Science Standards (2011) to motivate massive numbers of students to undertake advanced study of the sciences.

\section{Illustration 9. Barbara Bell's Minimus (2000) is the first of a series that includes an audio CD and two spiral-bound Teacher's Resource Books (2000, 2004 from Cambridge University Press.}

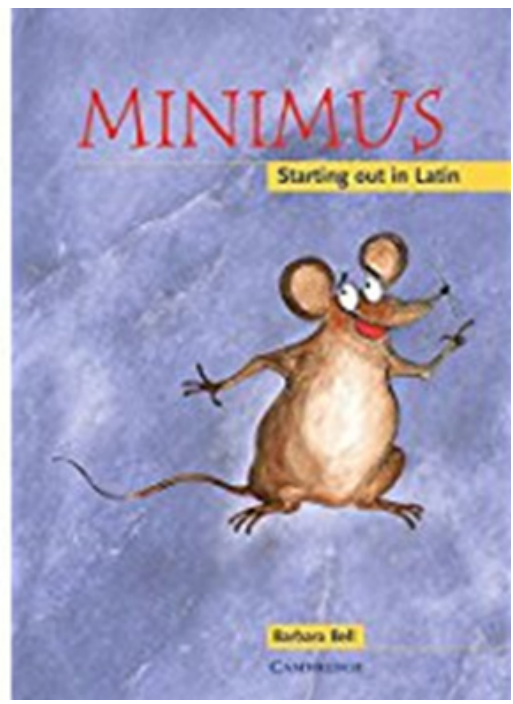

The materials are available to interest children in Latin as a foundation for subsequent mastery of scientific Latin. Resources are extensive: Barbara Bell's Minimus Pupil's Book: Starting Out in Latin (2000), the follow up Mininus Secundus (2004), an associated Latin Activity Book (2005), and a Minimus Audio CD (2006) provide accessible approaches. All carry the 
impressive imprimatur of Cambridge University Press. Aaron Larsen draws on the now-outdated but nostalgic idea of the "primer" in his Latin for Children: Primer $A$ and Primer B (2003) supported by a Primer A DVD (2006)—with options of "classical or ecclesiastical pronunciation".

Meanwhile, as fossils of ancient human ancestors keep turning up, the Linnean system of binomial nomenclature remains the system to which all discoveries must submit. Raymond Hart (1925) began it when he applied the term Australopithecus africanus ("Southern ape of Africa") to a primitive skull found near Taung, South Africa. Donald Johanson added Australopithecus afarensis ("Southern ape-man of Afar) to his 1974 discovery of "Lucy," at Afar. Since then, the ancestral lineage of Latinized ancestors has grown at an accelerating pace. A 1975 fossil discovery of fossils in close association with an advanced lithic tool worksite has led to Homo ergaster ("Worker Man"). A fully bipedal human discovered in 1991 in Georgia is named Homo erectus. European fossil discoveries in the 1990s of a species regarded as a predecessor or ancestor of later European humans are termed Homo antecessor. A 2014 discovery of pigmy-size humans on the Indonesian island of Flores has been designated Homo floresiensis. Most of these illustrate the Latinization of discovery locations or associated artifacts. Occasionally an oddity occurs. Homo naladi refers to a 2013 discovery of hominid fossils in the Rising Star Cave system of South Africa. Naladi means "star" in the Sotho-Tswana languages; interestingly this species designation escaped Latinization because it already resembled a Latin masculine adjective.

Despite the sophistication of Linnean binomial nomenclature, specimens turn up that resist classification. This has occurred with extinct species of plants, various animals, a number of birds, even bacteria where taxonomic description leaves questions or specialist controversies develop; such specimens remain in a taxonomic limbo. In a seminal paper, S. C. Matthews $(1972,714)$ discussed the occasional need for "open nomenclature," necessitated by uncertainty of classification: "Incertae familiae (Family uncertain), Incerti subordinis (Suborder uncertain), Incerti ordinis (Order uncertain), Incerti sedis (Class uncertain)." This catch-all term for taxonomic puzzles gets periodic usage: in a discussion of ancient fossils from Iowa, Richard Arnold Davis (1975) refers to their "uncertain affinity." Graham J. Bird (2007) provides another example in a crustacean located in the deep trenches off the coasts of the Kamchatka Peninsula and Japan, designating it as "Family Incertae sedis." Sometimes removal of a puzzling specimen from "uncertain placement" is effected by the creation of a new Order, as happened with the California condor; in such cases, the specimen may be designated Species inquirenda, meaning its identification is doubtful and requires further investigation. The terms Incertae sedis ("Uncertain placement") and Species inquirenda ("Requiring additional investigation") illustrate the momentum of scientific Latin in providing descriptors even for biological specimens that momentarily defy placement within the standard Linnaean system. Within the Homo genus, we have an example in the recent discovery of a finger bone and molar in Denisova Cave in southern Russia. DNA sequencing has shown prehistoric mating of the Denisova Cave people with Neanderthals and markers reveal genetic penetration into Island Southeast Asia and Melanesia. But the relationship between Neanderthals, the Denisova Cave people, and the presumptive Homo erectus migrants out of Africa one to two million years ago, leaves precise taxonomy so far uncertain - a prime example within the hominid line of Incertae sedis. This is one situation when scientists are willing to resort to a popular nomenclature rather than forcing an uncertain Linnaean placement. To date, these newly discovered hominids are called, simply, Denisovans, just as their compatible cousins with whom they mated have for years been called, simply, Neanderthals. 


\section{Acknowledgment}

I would like to thank the anonymous reviewer, a self-taught student of Latin, who provided a thorough reading, useful observations, and specific suggestions for the improvement of this paper.

\section{References}

Alexander, Henry. 1940. The Story of Our Language. New York: Thomas Nelson \& Sons.

Algeo, John, and Thomas Pyles. 2005. The Origins and Development of the English Language. $5^{\text {th }}$ ed. Boston: Thomas Wadsworth.

Alvarez, Walter. 1997. T-Rex and the Crater of Doom. Princeton: Princeton University Press.

Alvarez, Walter, Alessamdro Montanari, David Shimabukuro. 2015. "Ex Libro Lapidum Historia Mundi: Reading History Written in Rocks," From Big Bang to Galactic Civilization: A Big History Anthology, ed. Barry Rodrigue, et al. Delhi: Primus Books. Vol. I, 42-53.

Aquinas, Thomas. 1981. The Summa Theologica. 5 vols. Christian Classics.

Bigelow, Jacob. 1814. Flurola Bostoniensis: A Collection of Plants of Boston. Cambridge: Hilliard and Mecalf.

Bird, Graham J. et al. 2007. "Family Incertae Cedis in Tanaidacea (Crustacea: Peracarida) from Japan III. The deep trenches; the Kurile-Kamchatka Trench and Japan Trench.” Zootaxa. 1599: 121-149.

Boethius. 1973. The Consolation of Philosophy. Trans. H. F. Stewart. Harvard: Loeb Classical Library.

Bragg, Melvyn. 2003. The Adventure of English: The Biography of a Language. New York: Arcade Publishing.

Brown, Roland Wilbur. 2000. The Composition of Scientific Words. Washington, DC: Smithsonian Institute.

Caesar, Julius. 1917. The Gallic War. Trans. H. J. Edwards. Harvard University Press: Loeb Classical Library.

Calvin, John. 1960. Institutes of the Christian Religion, 2 vols. Trans. Ford Lewis Battle. Philadelphia: Westminster Knox.
Chan-ard, Tanya, Jarujin Nabhitabhata. 2015. A Field Guide to the Reptiles of Thailand.

Singapore: Oxford University Press.

Cicero. 1933. On the Nature of the Gods. Trans. H. Rackham. Harvard University Press: Loeb Classical Library.

Copernicus, Nicholaus. 1999. De Revolutionibus Orbium Coelestium. Trans. A. M. Duncan. Norwalk: The Easton Press.

Curtius, Ernst Robert. 1953. European Literature and the Latin Middle Ages. Trans. Willard R. Trask. Princeton: Princeton University Press.

Richard Arnold Davis, Richard Arnold, et al. 1975. "Fossils of uncertain affinity from the Upper Devonian of Iowa." Science 187, No. 4173: 251-254.

Eiseman, Fred and Margaret. 1988. Fruits of Bali. Singapore: Periplus Editions.

Galilei, Galileo. 2016. Siderius Nuncius, or the Sidereal Messenger. Trans. Albert van Helden. Chicago: University of Chicago Press.

Jesperson, Otto. 1962. Growth and Structure of the English Language. Oxford: Basil Blackwell.

Kennedy, Robert S. 2000. A Guide to the Birds of the Philippines Paperback. Singapore: Oxford University Press.
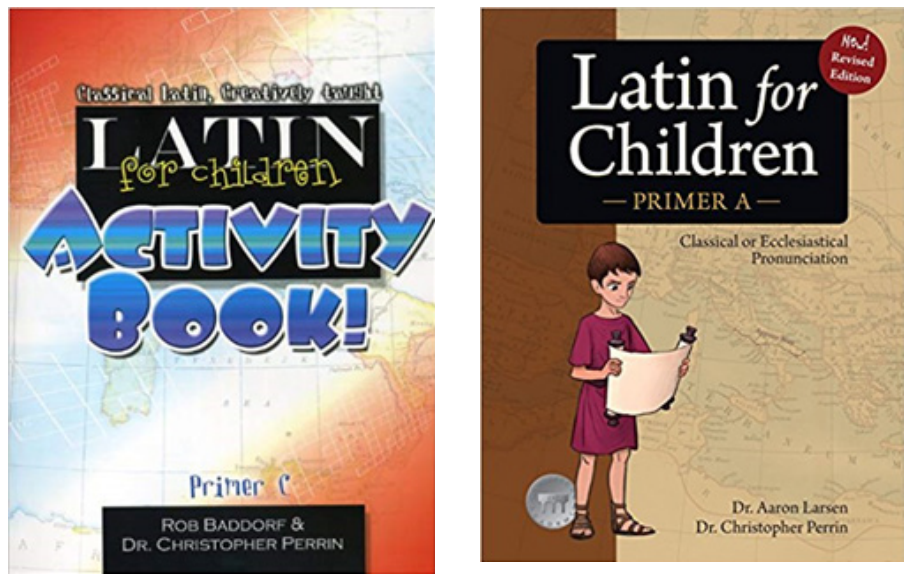

Illustration 10. Arron Lewis has produced a series-Latin for Children: Primer A and Primer B (2003) with a Latin for Children Activity Book, with support from a Primer A DVD (2006) 
Linnaeus, Carl. 1751. Philosophia Botanica. Oxford: Oxford University Press.

Linnaeus, Carl. 1753. Species Plantarum. UK: Ray Society Facsimile.

Linnaeus, Carl. 1753. Systema Naturae. Andesite Press.

Lovelock, James. 1988. The Ages of Gaia: A Biography of Our Living Earth. New York: W. W. Norton.

Margulis, Lynn, Karlene V. Schwartz. 1982. Five Kingdoms: An Illustrated Guide to the Phyla of Life on Earth. New York: W. H. Freeman and Company.

Matthews, S. C. 1973. "Notes on open nomenclature and synonymy lists." Palaeontology. 16 (4): 713-719.

Mora, Camilo, et al. "How Many Species are there on Earth and in the Ocean?" PLoS Biology 9 (8): e1001127. https://doi. org/10.1371/journal.pbio.1001127

Murphy, Bill. 2006. Greens Wetbank: Greens Bayou Wetlands Mitigation Bank. Houston: Houston Chronicle.

O'Neil, Maryadele J. 2001. The Merck Index: An Encyclopedia of Chemicals, Drugs, and Biologicals. $13^{\text {th }}$ ed. Whitehouse Station, NJ: Merck Research Laboratories.

Rossi, Paolo. 2000. The Birth of Modern Science. Trans. Cynthia De Nardi Ipsen. Oxford: Blackwell Publishing.

Sachs, Julius von. 1890. History of Botany: 1530-1860. Trans. Henry E. F. Garnsey. Oxford at Clarendon: Oxford University Press.

Serjeantson, Mary S. 1935. A History of Foreign Words in English. London: Kegan Paul, Trench, Trubner \& Company.

Stearn, William T. 1992. Botanical Latin: History, Grammar, Syntax, Terminology and Vocabulary. $4^{\text {th }}$ ed. Devon, UK: David \& Charles.

Thoreau, Henry David. 1868. A Week on the Concord and Merrimack Rivers. Cambridge: James Munroe \& Company.

Thoreau, Henry David. 1854. Walden, or Life in the Woods. Boston: Tickner \& Fields.

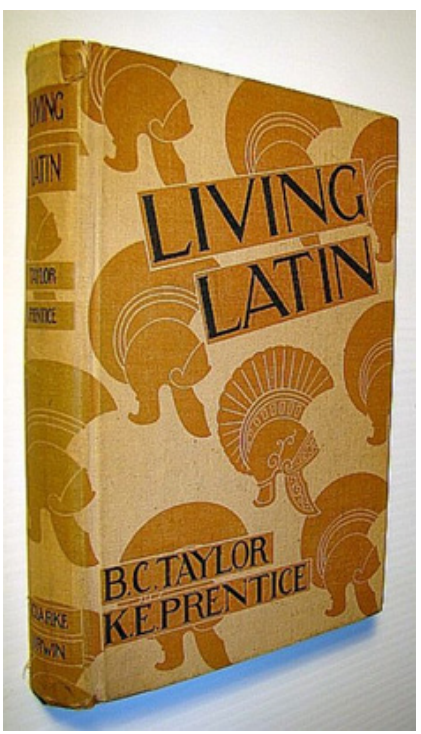

Illustration 11. B. C. Taylor and K. E. Prentice, Living Latin (Toronto: Clarke-Irwin \& Company, 1956) was the most widely used Latin Textbook in Canada until its publisher was purchased by Thomas Nelson Publishing in 2002 .

Thoreau, Henry David. 1864. Cape Cod. Princeton: Princeton University Press.

Thoreau, Henry David. 1865. The Maine Woods. Boston: Ticknor and Fields.

Thoreau, Henry David. 2000. Wild Fruits: Thoreau's Rediscovered Last Manuscript. Ed. Bradley P. Dean. New York: W. W. Norton.

Tournefort, Joseph Pitton de. 1694. Éléments de botanique ou methode pour connaître les plantes. Paris: Imprimerie Royale.

Watson, J. G. 1928. Mangrove Forests of the Malay Peninsula. Singapore: Fraser \& Neave.

White, John Williams. 1937. The First Greek Book. Boston: Ginn and Company.

Whitehead, Alfred North, Bertrand Russell. 1910-1913. Principia Mathematica, 3 vols. Cambridge: Cambridge University Press.

Wu, Xinzhi, "On the Origin of Modern Humans in China." Quaternary International Vol. 117, Issue 1, 2004, Pages 131140 